\title{
Predicting the Size Selectivity Based on the Striped Red Mullet Morphology (Mullus surmuletus) in Bottom Trawl Fisheries
}

\author{
Enis Noyan Kostak ${ }^{1}$ (D), Adnan Tokaç² (1) \\ Cite this article as: Kostak, E.N., Tokaç, A. (2018). Predicting the Size Selectivity Based on the Striped Red Mullet Morphology (Mullus surmule- \\ tus) in Bottom Trawl Fisheries. Aquatic Sciences and Engineering, 33(3): 90-95.
}

\begin{abstract}
The striped red mullet (Mullus surmuletus) is a commercially important demersal species caught by mixed trawl fishing in the Mediterranean Sea. Although it is not among the target species of bottom trawl operations, the striped red mullet is an important species due to its high commercial value in trawl catch composition. The primary target is to catch adult individuals while allowing the immature and juvenile fish to escape for sustainable fisheries using selective fishing gears. Various selectivity studies regarding trawl codends aimed at improving selectivity have been carried out in the past two decades. However, the selectivity sea trials generally require a great deal of work, time, and labor on the deck and are also expensive. Therefore, instead of experimentalbased selectivity studies, simulation-based studies (i.e., the FISHSELECT methodology) were recently started to predict the size selectivity of species in bottom trawl fisheries. In this study, sampled individuals of the striped red mullet were used in morphological measurements, fall-through experiments, and simulation phases. Diamond mesh sizes of 40,44, and $50 \mathrm{~mm}$ and a square mesh size of $40 \mathrm{~mm}$ of bottom trawl codends were simulated, and the L50 values were calculated as 9.87, 10.75, 12.19, and $12.3 \mathrm{~cm}$ for the aforementioned mesh sizes, respectively. Design guides were then created for various mesh sizes and opening angles. The study results were compared with those of previous studies on the red mullet ( $M$. barbatus) that were conducted using the FISHSELECT methodology, and the selectivity results of these two species were found to be similar.
\end{abstract} Keywords: FISHSELECT, striped red mullet, Mullus surmuletus, selectivity, bottom trawl

${ }^{1}$ Department of Fisheries, Ege University, Graduate School of Natural and Applied Science, İzmir, Turkey

${ }^{2}$ Department of Fish Capture and Processing Technology, Ege University, Fisheries Faculty, İzmir, Turkey

Submitted:

24.11.2017

Accepted:

27.03.2018

Correspondence:

Adnan Tokaç

E-mail:

adnan.tokac@ege.edu.tr

(c) Copyright 2018 by Aquatic

Sciences and Engineering

Available online at

dergipark.gov.tr/tjas

\section{INTRODUCTION}

Certain rules and guidelines have been established for the scientific use of resources in fisheries management. One of these is to prevent juveniles from being caught in fishing operations by means of selectivity and to ensure that fish populations are used in a sustainable manner. Using the morphological characteristics of fish, predicting the basic selectivity characteristics of fishing nets and adapting this to Mediterranean fisheries is one of the main objectives of such methods.

It has been reported that 30\% of the species caught in the Mediterranean and Black Sea are demersal species (FAO, 2011). Among these demersal species the striped red mullet (Mullus surmuletus) is one of the most commercially important species. According to the latest data, a total of 3,047 tons of fish were caught in the seas off Turkey (TUIK, 2016). 12,014 tons of striped red mullet were caught worldwide according to latest reports (FAO, 2014). Generally, gill net, trammel net and bottom trawling methods are used in the fishing of the striped red mullet.

Conventional selectivity studies are usually carried out by analyzes of experimental data obtained from sea trials. However, these studies are very expensive and require manpower and time. To avoid such problems, less experimental data is used in the theoretical selectivity prediction studies which have started to be used extensively in recent years. The relationship between the morphological characteristics of captured species and mesh openings can be examined in terms of selectivity through these studies. 
Izmir Bay and the vicinity were selected as the study area. In this region, there is intensive fishing of the striped red mullet. Generally, gill and trammel nets are using as fishing methods but bottom trawling is also used as a method although, in this case, the red mullet is not among the primary target species. It also shows morphologically significant similarities with the red mullet which indicates that the comparative selectivity properties of these two species can be studied. Thus, problems that can be encountered in fisheries management could be solved much more quickly and scientifically.

To briefly mention the similarities between the striped red mullet and the red mullet, the striped red mullet has a longer snout structure than the red mullet. In addition, the red mullet has a more perpendicular head shape than the striped red mullet. The red mullet also has a purple-maroon color while the striped red mullet has a red stained body color. The striped red mullet has a clear red line on the lateral side starting from the back of the eye, above which there are three yellow lines extending up to the caudal keel.

In conventional selectivity studies, the main method of evaluating selectivity is based on obtaining experimental data with sea expeditions and analyzing this data statistically. But during trawl hauling, difficulties and unpredictable conditions can arise such as streams, weather, equipment, crew etc. If we take these variable factors into consideration, many high cost and time-consuming expeditions at sea are required to get reliable results. Scientists have introduced many methods to solve these problems. The FISHSELECT methodology, which simulates and predicts codend selectivity based on fish morphology (Herrmann et al., 2009), could be one of the solutions to such issues in sustainable fisheries managment.

This method has already been applied in a number of studies to estimate the selective properties of codends of towed fishing gears for larger species of some round fish (Herrmann et al., 2009, 2012; Krag et al., 2011; Sistiaga et al., 2011), flatfish (Herrmann et al., 2013), nephrops (Frandsen et al., 2010) and krill (Krag et al., 2014). This method was also used on the red mullet as a Mediterranean species (Tokaç et al., 2016). The results of these studies show that there is a similarity between the estimated and actual results when compared with actual marine selectivity studies. This is the first theoretical basis selectivity study on the striped red mullet, which has an economically important place in bottom trawl catch composition.

Table 1. Striped red mullet (Mullus surmuletus) experimental selectivity data for diamond mesh and square mesh codends. $n$ denotes the number of open meshes in codend circumference

\begin{tabular}{lcccc}
\hline $\begin{array}{l}\text { Nominal/ } \\
\text { Measured } \\
\text { Mesh Size }\end{array}$ & $\begin{array}{l}\text { L50 } \\
(\mathrm{cm})\end{array}$ & $\begin{array}{c}\text { SR } \\
(\mathrm{cm})\end{array}$ & $\mathrm{n}$ & References \\
\hline $40 \mathrm{~mm}$ Square & 12.2 & 2.1 & - & Ordines et. al., 2006 \\
$40 \mathrm{~mm}$ Diamond & 9.8 & 2.9 & 51 & Ateş et. al., 2010 \\
$40 \mathrm{~mm}$ Square & 13.2 & 3.2 & 28 & Ateş et. al., 2010 \\
\hline
\end{tabular}

\section{MATERIAL AND METHOD}

\section{Study Area and Experimental Selectivity Data}

In this study, the striped red mullet was used as a material. The striped red mullet is a demersal species belonging to the Actinopterygii class, Perciformes order, Mullidae family. The striped red mullet has a relatively high commercial value among other species caught by bottom trawl fishing in the Mediterranean Sea. Although there were not enough selectivity studies on trawl fisheries of this species, published historical study results are listed below with retention rates (L50) and selection range (SR) (Table 1).

The FISHSELECT method was used in this study. This method has three different phases, in chronological order; sea trials, laboratory phase, simulation analyzes.

Individual samples were collected from İzmir Bay and bought fresh and with no deformities from fish auctions in the Izmir region. A total of 65 fish from the smallest to the largest possible size of the species were obtained and used in this study. Species are sampled according to length-frequency data about the striped red mullet population in Izmir Bay (ilhan et al., 2009). Specimens were brought to the laboratory before body deformation such as dehydration and rigor mortis occurred.

\section{Measuring Fish Morphology}

Fresh samples were transferred directly to the laboratory for length and weight measurements. A weight scale (TypeBD6000: Mettler, USA) of $0.01 \mathrm{gr}$ precision was used during this process. Measured weights were recorded in grams. To take size measurements, a specially designed PVC ruler was used.

A morphometer was used for body cross section measurements, which are required for the simulation study. Cross sections (CS) are coded as CS1 and CS2 (Figure 1). CS1, a spiny structure located in the middle of the opercula which is located at the widest bony part of the head, and CS2, the foremost point of the spiny dorsal which is located at the point of the maximum transverse perimeter, fin were used for the red mullet cross section measurements in Tokaç et al., 2016.

These cross sections were determined using a morphometer and were scanned by a flatbed scanner and these measurements were marked and digitized by computer using FISHSELECT software (Figure 2).

\section{Fall-through Experiments}

A new set of mesh templates comprised of 478 different mesh shapes, were made specifically to carry out fall-through experiments for small fish species. Mesh templates were made from $4 \mathrm{~mm}$ thick solid polyethylene material (Figure 3). Each fish was held by the tail and dropped into the mesh templates upsidedown. The template plates were held horizontally and each fish turned optimally to fall through the mesh. The only force that influenced the fish was gravity as they faced the mesh templates (Herrmann et al., 2009). At the end of this experiment, it was decided whether or not fish passed through plates. 


\section{Simulation of Mesh Penetration and Selection of a Penetra- tion Model}

After length and weight data obtained in the laboratory were converted into a list called a fish list, a mesh list was created which includes 478 different mesh models representing mesh sizes from 20 to $245 \mathrm{~mm}$. The shapes include diamonds (252 meshes), hexagons (98 meshes) and rectangles (128 meshes).

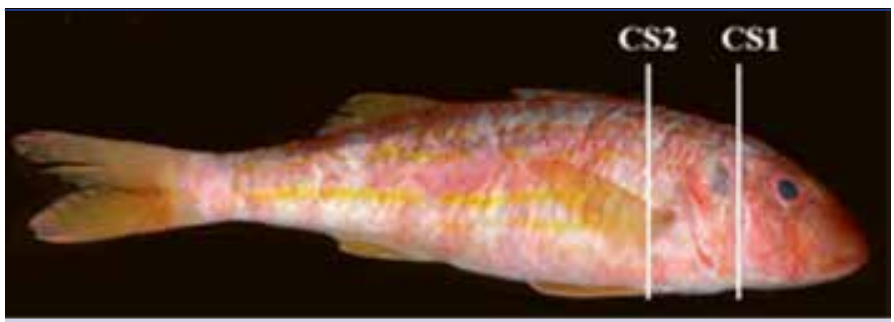

Figure 1. Cross section positions

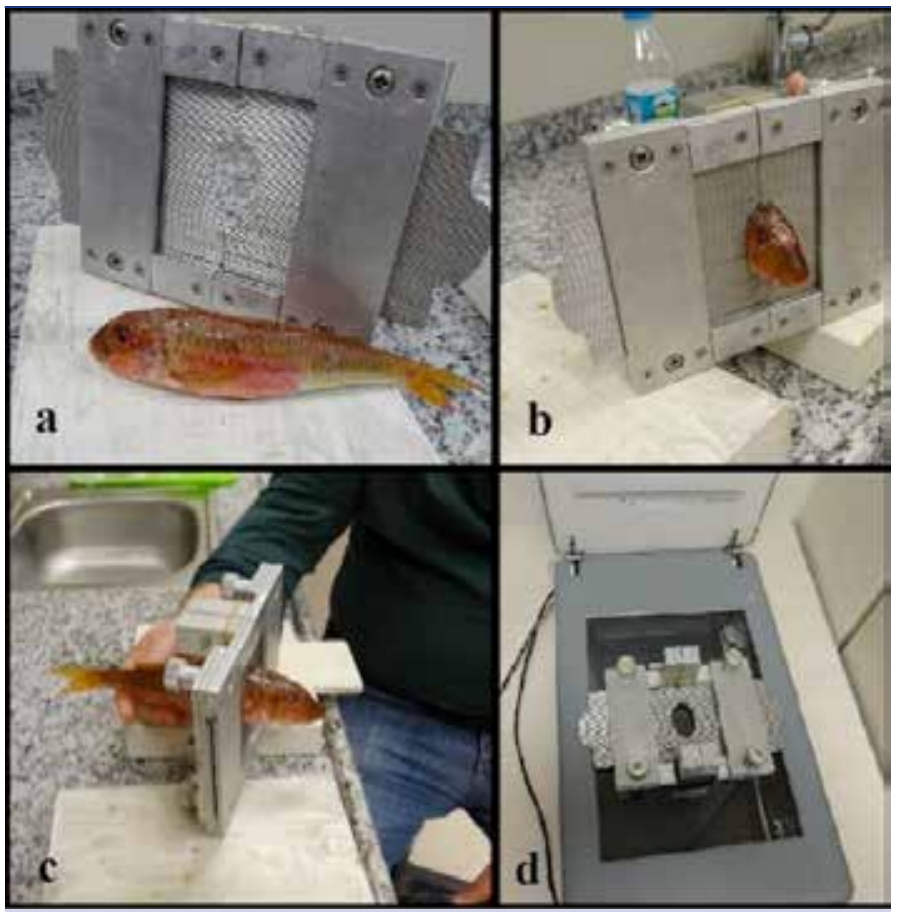

Figure 2. a-d. (a) Morphometer and sample, (b) CS1 measurement, (c) CS2 measurement, (d) Flatbed scanner

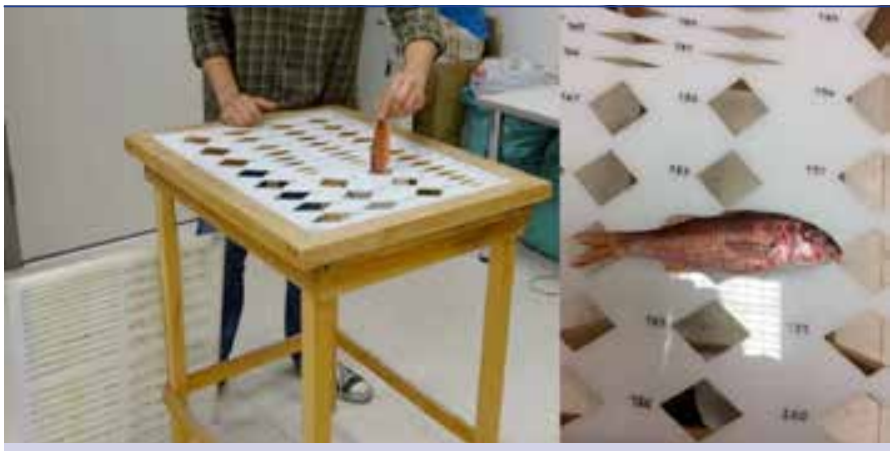

Figure 3. Fall-through experimental setup
By using the cross-sectional body models available in the program, the closest matching model for each digitised cross section was determined as the most appropriate model for the relevant cross section. At this stage, 3 cross-section models: ellipse, flexellipse and flexdrope shapes were chosen for analyzes. These cross-sections were chosen for their potential to determine a striped red mullet's ability to pass through meshes of different configuration and size size and shape.

After the determination of the cross-sectional shapes, the compression ratio was estimated. In order to make the closest estimate of the results obtained in laboratory studies, the tissue stiffness differences in the dorsal, lateral and abdominal regions were estimated and the compression rates were calculated. Compression models obtained for cross-sections were compared with fall-through experiment results and simulated by FISHSELECT. The simulation process varies depending on the processing performance of the computer, however, in this study, it took approximately two weeks. The most appropriate model was then selected for the best resultant compression model type.

A virtual population of 5,000 individuals was created for use in predict size selectivity regarding length-weight distributions of 65 specimens morphological data. The selected best compression model was tested along with the mesh size and virtual population, and the selectivity parameters for mesh sizes were calculated. These were determined as the $50 \%$ retention rate (L50) selectivity parameter of the species. All these results were transformed into the design guide with the help of $\mathrm{R}$ statistic program. These isobar graphics show all retention rate possibilities and help us to estimate theoretical selectivity of target species.

\section{RESULT AND DISCUSSION}

A total of 65 striped red mullet individuals were sampled and ID numbers for each fish were created (Figure 4). Sampled species were measured and found to be between 87-234 mm and 4-192 $\mathrm{g}$ in length and weight, respectively. This data was recorded in the FISHSELECT software for the study.

\section{Fish Shape and Cross Section Analyzes}

The striped red mullet has a fusiform body shape. According to this shape, three similar forms were chosen; ellipse, flexellipse1 and flexdrope. Cross sections have been imaged from a flatbed scanner and those images pinpointed from their edges one by one, each image is marked with at least 120 dots to enable the shape of the most suitable model to be analyzed (Figure 5).

To determine the most suitable shapes for CS1 and CS2 separately, the mean AIC (Akaike, 1974) and $\mathrm{R}^{2}$ values were calculated for each striped red mullet individually for each of the three models for both CS1 and CS2. The highest $\mathrm{R}^{2}$ and the lowest AIC values were considered as parameters. According to this analysis, the most suitable body shape has been found as the flexellipse1 model (Table 2).

\section{Fall-through Results and Penetration Model}

Fall-through pass results were recorded as yes or no for the 65 samples for each of the 478 meshes with varying sizes of open areas and a total of 31,070 trials were completed. Based on the results of these fall-through trials, we selected a penetration model 
(compression model) to use for simulating size selection of the striped red mullet.

This process determines the best model to be used in selectivity simulations by entering the estimated compression rates for the most appropriate model obtained from analyzes of fall-through experiments and cross sections. The maximum compressibility estimated for this model was $20 \%$ lateral, $6 \%$ dorsal and $30 \%$ ventral. A combination of different compression rates determined for each side resulted in $6 \times 4 \times 6=144$ compression models (Table 3 ).

Virtual simulation was carried out by selecting the best 5 models obtained from the result of the fall-through experiments. The simulation was then carried out based on the degree of agree-

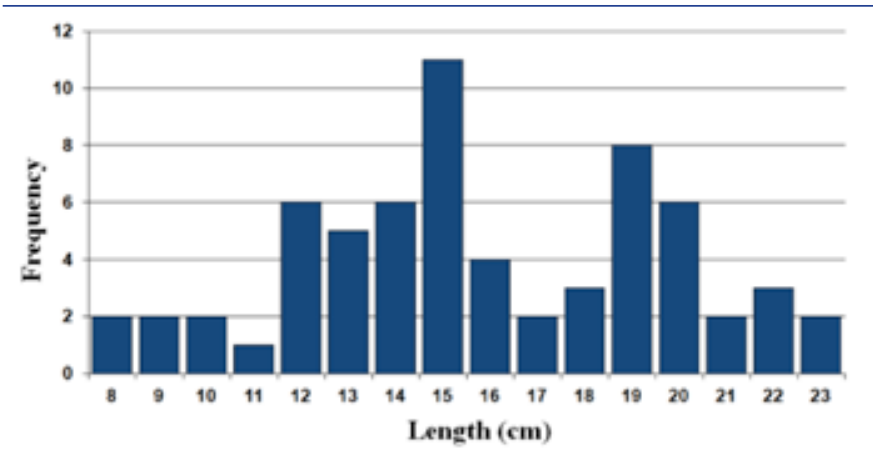

Figure 4. Length/frequencey histogram graphic of sampled 65 species

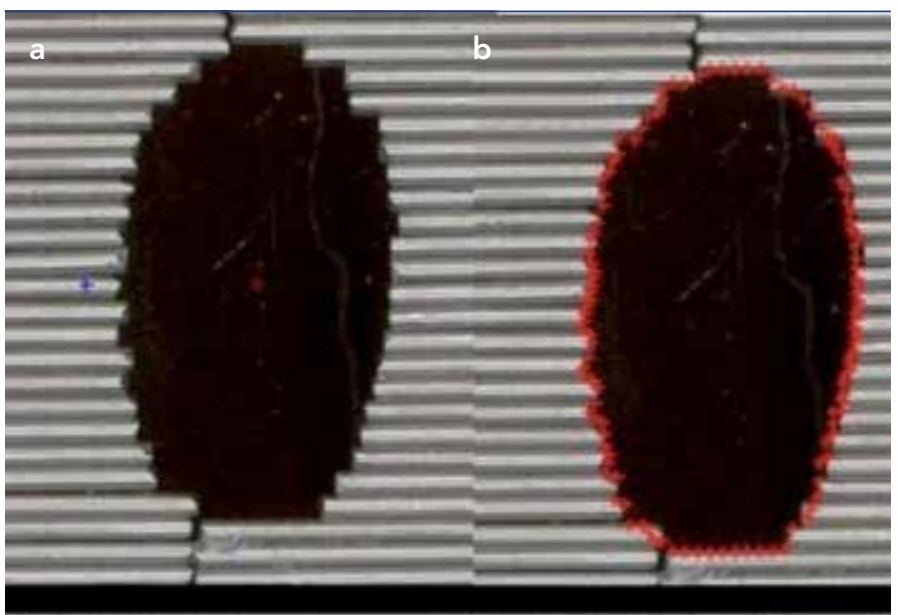

c

\section{d}

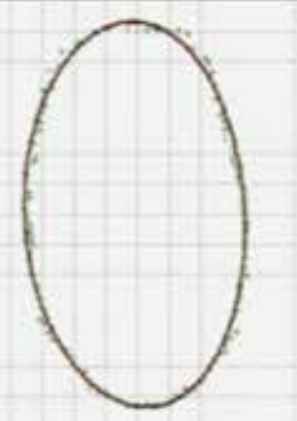

Figure 5. a-d. (a) Scanned raw image (b) Edge marking (c) Digitalised CS (d) CS model selection ment value (DA-value) for the different models compared with these fall-through experiments result.

S: The number of successful test results compared with the model's free pass result

D: The number of unsuccessful test results compared with the model's free pass result

$\mathrm{DA}=\frac{\mathrm{S}}{\mathrm{S}+\mathrm{D}}$

The model with the highest value of 0.95 above the acceptance grade was chosen as the best model for both cross sections (CS1 and CS2) and was selected for the compression model (Table 4).

A virtual population of 5,000 individuals was created based on the length-weight data of the 65 samples. The recalculation of the compression values to $+/-0.01$ resulted in a test with $3 \times 3 \times 3$ $=27$ possible combinations of compression, and a virtual simulation has been run. As a result, the highest DA value model was found to be as the best compression model (Table 5).

When the compression models were examined, it was seen that the model giving the highest result belongs to the CS2 coded section with a rate of $97.19 \%$. Estimated compressions were found as $4 \%$ from lateral, dorsal $2 \%$, ventral $18 \%$ at the end of the simulation.

Table 2. Mean $\mathrm{R}^{2}$ and $A I C$ values for different shape descriptions. The highest $R^{2}$ and lowest AIC values for each cross section are in bold

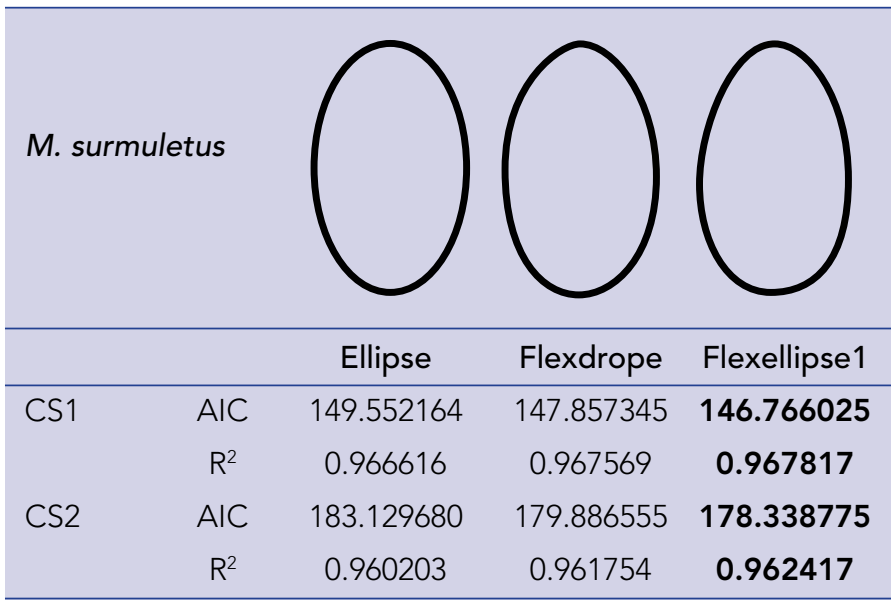

Table 3. Estimated compression rates matrix

\begin{tabular}{lcc}
\hline Comp0 & Comp90 & Comp270 \\
\hline 1.00 & 1.00 & 1.00 \\
0.96 & 0.98 & 0.94 \\
0.92 & 0.96 & 0.88 \\
0.88 & 0.94 & 0.82 \\
0.84 & & 0.76 \\
0.80 & & 0.70 \\
Total Compression Model Number:6x4×6=144 & \\
\hline
\end{tabular}




\section{Design Guides}

The size selection predicted by FISHSELECT can be applied to produce design guides in the form of iso-curves for $L 50$ values dependent on mesh size and mesh openness (Tokaç et al., 2016) With the help of the R statistics program, design guides have been created. Diamond and square mesh types have been designed in two guides (Figure 6, 7). In addition, it has been plotted the FISHSELECT predicted $L 50$ values for $40^{\circ}$ opening angle (OA). This specific OA value was reported by Tokaç et. al., 2016 as the typical value for meshes observed during trawling from underwater recording.

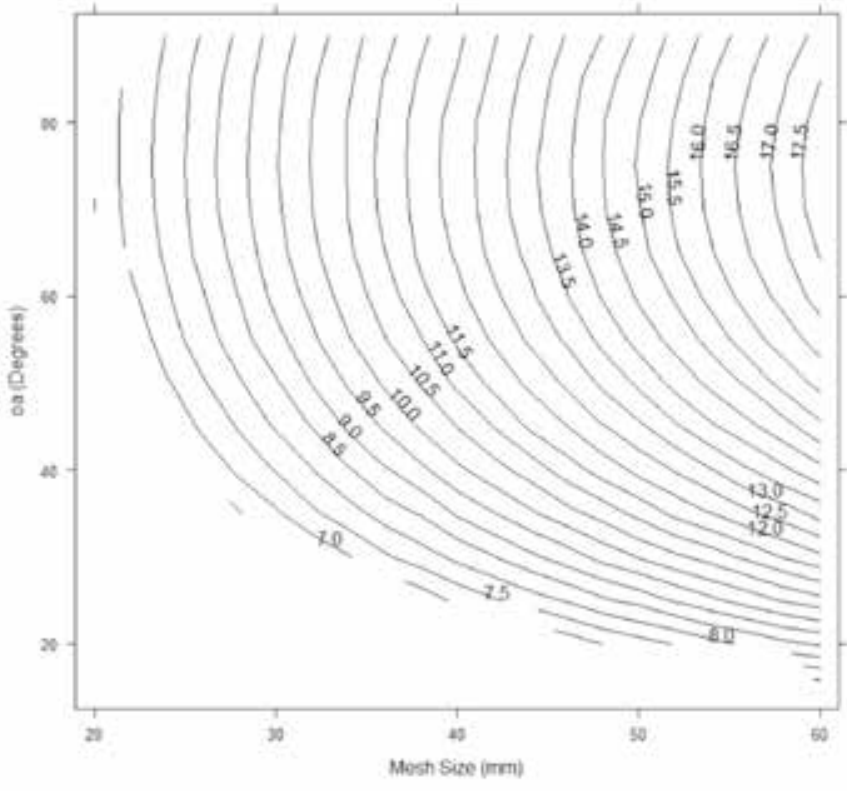

Figure 6. Design guide for diamond mesh

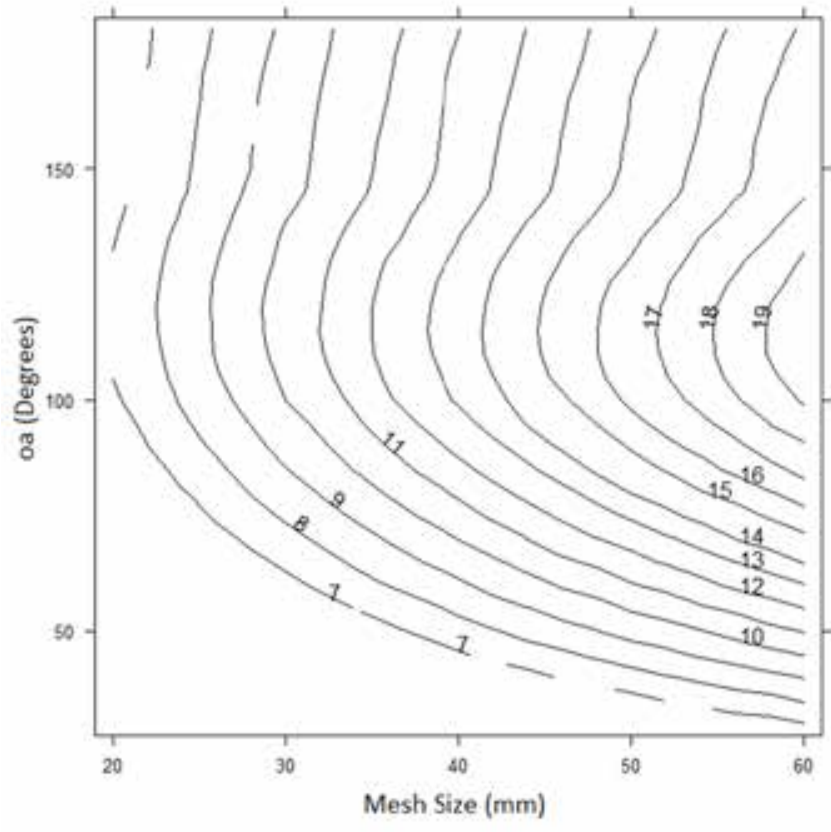

Figure 7. Design guide for square mesh
Diamond mesh codend $L 50$ values for $40 \mathrm{~mm}, 44 \mathrm{~mm}, 50 \mathrm{~mm}$ mesh sizes are predicted as $9.87 \mathrm{~cm}, 10.75 \mathrm{~cm}, 12.19 \mathrm{~cm}$ striped red mullet. Square mesh codend L50 retention rates are predicted as $12.38 \mathrm{~cm}$ mean value between $70^{\circ}$ and $120^{\circ} \mathrm{OA}$ which are estimated $\mathrm{OA}$ values during bottom trawl towing (Table 6).

Diamond mesh codend with $40 \mathrm{~mm}, 44 \mathrm{~mm}$ and $50 \mathrm{~mm}$, and 40 $\mathrm{mm}$ square mesh codend were used in the study in accordance with the European Union's (1995/2006) mandatory regulation and the recommendations of the General Fisheries Commission for the Mediterranean on mesh sizes.

When the results obtained were examined, it was concluded that it is difficult to make a precise and clear comparative analyzis due to incomplete and inadequate previous studies. However, if we compare the results obtained in the controlled computer environment with the actual selectivity studies, it can be seen that

Table 4. Best 5 models that given highest results for both cross sections. Best resultant model is marked in bold

\begin{tabular}{ccccccc}
\hline & \multicolumn{7}{c}{ CS 1 } \\
\cline { 2 - 7 } & comp0 & comp90 & comp270 & S & D & DA \\
\hline 1 & 1.00 & 1.00 & 1.00 & 29835 & 1235 & 0.96025 \\
2 & 1.00 & 0.98 & 1.00 & 29779 & 1291 & 0.95844 \\
3 & 1.00 & 0.96 & 1.00 & 29723 & 1347 & 0.95664 \\
4 & 1.00 & 1.00 & 0.94 & 29663 & 1407 & 0.95471 \\
5 & 1.00 & 0.94 & 1.00 & 29658 & 1412 & 0.95455 \\
& & & CS 2 & & & \\
\hline 1 & 0.96 & 0.98 & 0.82 & 30715 & 895 & 0.97119 \\
2 & 0.96 & 1.00 & 0.82 & 30165 & 905 & 0.97087 \\
3 & 0.96 & 1.00 & 0.76 & 30158 & 912 & 0.97064 \\
4 & 0.96 & 0.96 & 0.82 & 30156 & 914 & 0.97058 \\
5 & 0.96 & 0.98 & 0.76 & 30152 & 918 & 0.97045
\end{tabular}

Table 5. Compression results end of precise simulation gives the best model

\begin{tabular}{lllllll}
\hline & \multicolumn{5}{c}{ CS 2 } \\
\cline { 2 - 7 } & comp0 & comp90 & comp270 & S & D & DA \\
\hline $\begin{array}{l}\text { Best } \\
\text { Compression }\end{array}$ & & & & & & \\
Model & 0.96 & 0.98 & 0.82 & 30197 & 873 & 0.97190 \\
\hline
\end{tabular}

Table 6. Important $L 50$ values from this study

\begin{tabular}{lccc}
\hline Mesh Opening Angle & Mesh Size & Mesh Shape & $\mathrm{L}_{50}$ \\
\hline $40^{\circ}$ & $40 \mathrm{~mm}$ & Diamond & $9.87 \mathrm{~cm}$ \\
$40^{\circ}$ & $44 \mathrm{~mm}$ & Diamond & $10.75 \mathrm{~cm}$ \\
$40^{\circ}$ & $50 \mathrm{~mm}$ & Diamond & $12.19 \mathrm{~cm}$ \\
$70^{\circ}$ & $40 \mathrm{~mm}$ & Square & $11.21 \mathrm{~cm}$ \\
$120^{\circ}$ & $40 \mathrm{~mm}$ & Square & $13.56 \mathrm{~cm}$ \\
\hline
\end{tabular}


the results are close to the previous study results. In addition, if the selectivity study is compared to that of numerous previous studies of the red mullet, it shows that the selectivity parameters between the two species are very similar.

In the previous FISHSELECT study (Tokaç et al., 2016) the red mullet had $L 50$ value in $40 \mathrm{~mm}$ and $50 \mathrm{~mm}$ diamond mesh size predicted as $11.0 \mathrm{~cm}$ and $13.5 \mathrm{~cm}$ respectively. When the comparison result was reviewed both species showed similar results, which is thought to be due to the low morphological differences between the two species. Due to the fact that the red mullet has a more perpendicular head structure than the striped red mullet, result L50 values are thought to be lower for the striped red mullet.

As can be seen from the design guide (Figure 6), $44 \mathrm{~mm}$ diamond mesh codend was found to be the most appropriate for the striped red mullet when we compare this result with its minimum landing size (MLS) $11 \mathrm{~cm}$.

Based on the results of the 31,070 fall-through trials, a compression model has been selected to use for simulating size selection of striped red mullet. This model consists of CS2 and resulted in a DA-value of $97.19 \%$. The compressibility for this model at CS2 was $4 \%$ lateral, $2 \%$ dorsal and $18 \%$ ventral. These compression rates can be related to the fact that the dorsal area has a bony structure because of the spine and skull, towards the lateral area tissue starts to lose stiffness and at the ventral area the abdominal tissue is soft.

\section{CONCLUSION}

The prediction of the size selection for trawl codends in different mesh size and shapes can be easily done using the design guides for guidance and, hence, can be a useful tool for sustainable fisheries. In this study, the FISHSELECT methodology was used with only one species to obtain cross section data defining the striped red mullet's ability to penetrate different mesh configuration and sizes. This methodology can also be used to predict the selectivity for other species relatively easily and quickly at a low cost.

Like other FISHSELECT studies, this study shows that selective studies conducted with laboratory and computer experiments give reliable results. It is suggested that further studies on similar selectivity methods should be conducted on the same species or different species and should be compared and interpreted with these and previous studies.

One of the most important problems is the pressure of overfishing of the fish stocks with by-catch. Useful technical measures should be found, such as improving codend selectivity for sustainable fisheries. The FISHSELECT methodology is of crucial importance in order to provide solutions by predicting the size selectivity for different species versus different mesh size and mesh configuration in the mixed bottom trawl Mediterranean fishery.

\section{Acknowledgements}

The research documented in this paper was conducted as part of the Ege University Scientific Research Project No: 16-SÜF-008 supported by the The Scientific Research Commission of Ege
University and it is also part of MSc thesis of Enis Noyan Kostak. This study was awarded 'Best oral presentation' in the 19th National Fisheries Symposium of Turkey which was organized by Sinop University between 12-15 September 2017.

\section{REFERENCES}

Akaike, H. (1974). A new look at the statistical model identification. IEEE Transactions on Automatic Control, 19(6), 716-723. [CrossRef]

Ateş, C., Bök, T., Alicli, T.Z., Kahraman, A.E., Göktürk, D., Ulutürk, T., (2010). Selectivity of diamond and square mesh beam trawl codends for European hake and striped red mullet in the Sea of Marmara, Turkey. Journal Animal and Veterinary Advances, 9(2), 436-440. [CrossRef]

FAO, (2011). Review of the State of World Marine Fishery Resources. FAO Fisheriesand Aquaculture Technical Paper No. 569, Rome.

FAO, (2014). Global Capture Production for Species, FAO FishStats, Available from: http://www.fao.org/fishery/species/3207/en (accessed 21.11.2017)

Frandsen, R.P., Herrmann, B., Madsen, N. (2010). A simulation-based attempt to quantify the morphological component of size selection of Nephrops norvegicus in trawl codends. Fisheries Research, 101(3), 156-167. [CrossRef]

Herrmann, B., Krag, L.A., Frandsen, R.P., Madsen, N., Lundgren, B. and Stæhr, K.J. (2009). Prediction of selectivity from morphological conditions: Methodology and a case study on cod (Gadus morhua). Fisheries Research, 97(1), 59-71. [CrossRef]

Herrmann, B., Sistiaga, M.B., Nielsen, K.N., Larsen, R.B. (2012). Understanding the size selectivity of redfish (Sebastes spp.) in North Atlantic trawl codends. Journal of Northwest Atlantic Fishery Science, 44, 1-13. [CrossRef]

Herrmann, B., Sistiaga, M., Larsen, R.B., Nielsen, K.N. (2013). Size selectivity of redfish (Sebastes spp.) in the Northeast Atlantic using gridbased selection systems for trawls. Aquatic Living Resources, 26(2), 109-120. [CrossRef]

İlhan, D.U., Akalın, S., Özaydın, O., Tosunoğlu, Z., Gurbet, R. (2009). İzmir Körfezi'nde Tekir Balığı'nın (Mullus surmuletus L., 1758) Büyüme ve Üremesi. Ege University Journal of Fisheries \& Aquatic Sciences, 26, 1-5.

Krag, L.A., Herrmann, B., Madsen, N., Frandsen, R.P. (2011). Size selection of haddock (Melanogrammus aeglefinus) in square mesh codends: A study based on assessment of decisive morphology for mesh penetration. Fisheries Research, 110(2), 225-235. [CrossRef]

Krag, L.A., Herrmann, B., Iversen, S.A., Engås, A., Nordrum, S., Krafft, B. A. (2014). Size selection of Antarctic krill (Euphausia superba) in trawls. PLoS One, 9(8), e102168. [CrossRef]

Ordines, F., Massutí, E., Guijarro, B., Mas, R. (2006). Diamond vs. square mesh codend in a multi-species trawl fishery of the western Mediterranean: effects on catch composition, yield, size selectivity and discards. Aquatic Living Resources, 19(4), 329-338. [CrossRef]

Sistiaga, M., Herrmann, B., Nielsen, K.N. and Larsen, R.B. (2011). Understanding limits to cod and haddock separation using size selectivity in a multispecies trawl fishery: an application of FISHSELECT. Canadian Journal of Fisheries and Aquatic Sciences, 68(5), 927. [CrossRef]

Tokaç, A., Herrmann, B., Gökçe, G., Krag, L.A., Nezhad, D.S., Lök, A., Kaykaç, H., Aydın, C., Ulaş, A., (2016). Understanding the size selectivity of red mullet (Mullus barbatus) in Mediterranean trawl codends: A study based on fish morphology. Fisheries Research, 174, 81-93. [CrossRef]

TUiK (Turkish Statistical Institute), (2016). Quantity of caught sea fish report. Available from http://www.tuik.gov.tr/PreTablo.do?alt_id=1005 (accessed 23.11.2017) 